\title{
A reciprocitás szerepe a mai perui falusi társadalomban (Antoinette Molinié-Fioravanti)
}

\author{
Eredetileg megjelent: George Dalton (ed.) \\ 1981: Research in Economic Anthropology - A Research Annual, \\ Volume 4, Jai Press Inc., PP. 54-58. \\ FordítotTa: GaÁl Dezsô 1999
}

Nanthan Wachtel a reciprocitás fogalmának segítségével elemzi az Inka társadalmat. Ez a megközelítés alkalmas a perui falusi társadalom fejlôdésének vizsgálatához is. A perui paraszti közösségekre egyre erôteljesebb befolyást gyakorol a piac. Ezt a hatást erôsíti a napjainkban folyó agrárreform is. A hagyományos csoportok, melyek határait korábban a rokonság határozta meg, vagyoni osztályokként fokozatosan újradefiniálódnak. Emellett továbbra is múködnek a korábbi termelési formák és ideológiák. Nem mintha ez a túlélés központi kérdése lenne. Inkább a piachoz való alkalmazkodás sajátos, andokbeli módjának tekinthetjük, miközben tovább él a hagyományos reciprocitás is. Ezt a folyamatot a Yucay-völgy példájával fogom illusztrálni, mely az Urubamba-folyónál, Cuzcótól 30 kilométerre, észak-keleti irányban fekszik.

A század elejéig Cuzco nagybirtokosainak (haciendas = nagybirtokok) öt paraszti ayllu egészen kicsi ültetvényével kellett számolniuk. A régió piaci integrációja, valamint a parasztok közötti differenciálódás szempontjából két tényezô bizonyult meghatározónak. Egyrészt a mulattok (arrieros) növekvô gazdagodása, akik az utak megépítése elốtt monopolizálták mind a völgyek, mind pedig a távolabbi vidékek fennsíkjai közötti kereskedelmet. Másrészt néhány kisebb földtulajdonos gyümölcs- és zöldségültetvényei segítségével nyereséghez jutott, s ezáltal Cuzco városában fokozatosan kiépült egy piac. 
Ennek ellenére a termelési viszonyokat bizonyos mértékben még mindig a reciprok viszonyok uralják. Hagyományosan, amikor egy parasztnak többletmunkára van szüksége, az aynihoz folyamodik. Az ayni a kölcsönös segítség hagyományos formája - legyen szó akár munkáról, akár ünnepre történô felkészülésrốl. Néhány nappal az aratás kezdete elốtt a paraszt felkéri egy rokonát vagy egy barátját, hogy segítsen neki. Hogy kedvezó választ kapjon, családja kíséretében carińot - azaz nagyra becsült ajándékot, például cigarettát vagy alkoholt - visz magával. Miután a carińot elfogadták (mindig el kell fogadni), erốs elkötelezettség alakul ki a partnerek között és megkezdôdik a reciprok cserék sorozata. Az így megnyert parasztok vidám hangulatban dolgoznak. A nyugati szemlélố meglepódik az alacsony termelékenységen. Ha összehasonlítjuk az aynira kiadott összegeket a bérekkel, azt látjuk, hogy egyenlôek, sốt, elôbbiek néha még magasabbak is. Azonban a régi intézményekhez való kötôdés túl erôs ahhoz, semhogy efféle számításokkal el lehetne szakítani.

Még a gazdagabb parasztok sem mindig tudnak teljes mértékben megfelelni az ayni követelményeinek, ami a viszonylag kiterjedt birtokukhoz szükséges. Így bérmunkásokat kell alkalmazniuk, akik a növekvố számú földtelen parasztokból kerülnek ki. Az ayni bizonyos vagyoni egyensúlyt igényel, s ennek csökkenése közvetlen kapcsolatban van a parasztságon belüli gazdasági egyenlótlenségekkel. Azonban a yucavino még jó bérért sem dolgozik soha chica (kukoricasör), picante (sült étel), vagy néhány tánclépés nélkül. A munkáltató is csökkenti egy kissé a jogos béreket azért, hogy munkásainak ünnepségeket tudjon rendezni. Ezenkívül figyelembe veszi az ayni rituáléját is: carińoval toboroz embereket; és - habár neki nincsenek kötelezettségei a bérmunkásokkal szemben - egy misztikus kötelék azt igényli, hogy munkásai gyermekeinek keresztapja legyen, hogy kölcsönadja nekik az ekéjét, hogy segítsen nekik. Így a reciprocitás régi kötelme értelmétôl megfosztva egyfajta ideológiai lepelként múködik egy olyan termelési folyamatban, amelyet alapjában a piac irányít; továbbá személyessé teszi a béralapú kapcsolatokat. 
Az indiánok közösségformáló viselkedésmódjai az ayni új formáiként öltenek testet. A szigorú egyensúly az adott és kapott dolgok között többé már nem áll fenn. Így az eke - amely a gazdagság jele - bérleti díja kifizethetô az ayni keretében (egynapi ekehasználati jogért cserébe négy napi munkával kell fizetni). Ugyanilyen módon bizonyos gazdag parasztok a kormánytól kapott mútrágyát munkára cserélik, s azt ayninak nevezik. Az intézmény ezáltal elveszti eredeti egalitáriánus lényegét és - paradox módon - segít elleplezni a gazdasági differenciálódást. Esetenként úgy tûnik, néhány új intézmény összhangban van mind a hagyományos kötelékekkel, mind az új piaci kapcsolatokkal: így a makipura köti össze az aynit a bérezéssel.

A földmúvest a társa segíti, aki ünnepi eledelt és egy kis pénzösszeget kap (napi 5-10 sol-t 30 helyett. 8 sol = 0,2 USD). Cserében ugyanilyen feltételekkel kell társát segítenie.

A jelenlegi termelési viszonyok között a vallási intézmények is leplezik az egyenlótlenséget, s ez megfelel a hagyományos kapcsolatoknak: a compadrazgo a reciprocitást ösztönzi, a cargo pedig a redisztribúciót.

Születéskor, az elsô hajvágás vagy a gyermek házassága alkalmából az apa és a keresztapa véglegesen compadres-ké válnak. Ez az alapvetô kötelék nem csupán a két egyént köti össze, hanem a két családot is. Bizonyos ünnepségek és könyörgések vezethetnek ezen kötelékek kialakulásához, melyek rendkívül kívánatosak, mivel amikor egy személyt felkérnek, hogy legyen compadre, közösségen belüli elismertsége minden alkalommal növekszik. A felek kötelesek minden dologban kölcsönösen segíteni egymást és nagyon erôs a társadalmi nyomás, hogy ennek a kötelezettségüknek eleget is tegyenek.

A faluban meglévô különbözô compadres-in keresztül a paraszt megpróbál egy spirituális családot felépíteni azért, hogy kárpótolja magát az igazi családja széteséséért. De valójában a compadres közötti kötelék a piac által létrehozott vagy kikényszerített egyenlőtlen 
kapcsolatokon belül létezik. A compadres nagyon különbözô társadalmi helyzettel bírnak. A paraszt mindig hatalommal bíró compadre-t akar, lehetôleg hacendadot (hacienda tulajdonos) vagy ennek compadre-ját. Így egy gazdag yucavino segítséget kér hacendado compadre-jétốl a kis hegyi falucskában élố szegény compadre-je számára és cserében a szegény compadre kisegíti a hacendado-t eladhatatlan feleslegének megvásárlásával. Ezen a módon egy kliensláncolat jön létre a vallási intézményen keresztül, mely az egyenlôség illúzióját adja számukra. A compadrazgo a reciprocitáson alapuló korábbi termelési formákból ered (ha van egy ajándék, akkor szükségképpen minden esetben van egy ellenkezô irányú ajándék is), ugyanakkor feltár egy bennszülött életmódot, illetve az egyenlôtlen viszonyok eltitkolásának módját is.

A cargo - amely úgy túnik, a tradicionális redisztribúción alapul - manapság hasonló funkciót tölt be. Minden évben bizonyos vallási ünnepnapokon a közösség egy tagja (egy carguyoc) vállalja magára az ünnep megrendezését. Ez mérhetetlenül sokba kerül, tönkremegy és eladósodik a carguyoc. A versengés ennek az intézménynek a legfontosabb jellegzetessége.

A század elején a cargoval kapcsolatos kiadások bizonyos parasztok csekély többletét emésztették fel. Ezen a módon tartották kézben a hacendadok a hatalmukra veszélyessé váló lehetséges vetélytársaikat. Meghívták óket a leggazdagabb parasztok rituális temetésére is, hogy pompás körülmények között trónoljanak az Emlékmú Téren.

Manapság a cargo kettôsséget mutat. Egyik oldalról tekintve a piaci versenytốl fenyegetett közösségi összetartás kedvéért újraosztja a javakat, másrészt viszont segít a piac által létrehozott egyenlótlenségek elrejtésében. Kétségkívül nagy nyomás nehezedik a gazdagokra, hogy vállalják a carguyoc szerepét. De manapság a carguyoc ritkán veszti el mindenét: az ünnepségek kevésbé fényúzóek, bár a parasztok gazdagabbak. Ellenkezôleg, a parasztok gazdagabbá válnak az ünnep után, abban az értelemben, hogy a gazdasági felsôbbségüket elismeri a közösség. Napjainkban mindenszentekkor min- 
dig ugyanazok a „kiválóságok” töltik be a carguyoc szerepét, akik a törvényhatóságnál (önkormányzatnál) tisztséget viselnek. Így például a kormányzó vagy más köztiszteletben álló, tekintélyes személyek. Ezenfelül ráadásul még a szentek között is hierarchia van, mely megfelel a carguyoc-juk gazdasági státusának. Röviden szólva úgy tûnik, ma a cargo nem más, mint néhány ember vagyonának elismerése és szentesítése a közösség által. Míg a század elején a hacendadok kényszerítették a parasztokat az egyenlôségük fenntartására, ma a közösség tartja fenn egyenlootlenségét redisztribúció színlelése által.

Ez viszont egy másik valóságot leplez: míg a termelés viszonyai jóval a falu határain túlról származnak, a cargo intézménye lehetôvé teszi, hogy a gazdasági versengés korlátozva legyen (a parasztok fejében) a falusi közösség szintjére; így elrejti az egyének közötti versengés mértékét.

A cargo jelentôsége rituálisan fejezôdik ki. Az ünnepi étkezés kezdetén a carguyoc egyenlô részekre osztja a különleges tésztából készült szent kenyeret, miközben a szent híveinek egyenlôségért és egységéért imádkozik. Cruzvelacuy ünnepén a kereszteket lehozzák a hegyrôl. Négy napig szigorúan meghatározott sorrendbe állítják óket, rangjuknak megfeleloón többé vagy kevésbé feldíszítve, többé vagy kevésbé vagyonos carguyoc által ünnepelve többé vagy kevésbé rangos ünnepségeken. Visszakerülve hegyi szentélyeikbe ismét egyenlôvé válnak: elveszítik ezüst ékköveiket és egyforma kápolnákban óriztetnek. A közösség, amely a földön a piac valósága által megosztott, az istenek eloótt az egységességrôl ábrándozik. 